\title{
BIRDS AND MAMMALS OF THE PINHORN PROVINCIAL GRAZING RESERVE*
}

by Hugh C. Smith, Provincial Museum and Archives of Alberta, Edmonton

The Pinhorn Provincial Grazing Reserve, a 76,760-acre tract of land located in townships 1 and 2 , ranges 7 and 8 , west of the 4 th meridian (Figure 1), is classified by Wyatt and Newton (1941) as virgin land. The Alberta Department of Lands and Forests administers the Reserve, and grazing leases are granted to local ranchers and farmers. During the summer approximately 3,000 head of cattle are run on this range, (unpublished, Department of Lands and Forests).

The area can be briefly described as a gently rolling grassland, sloping from south to north, with an elevation of 3,565 feet at the United States border to 3,000 feet at the northern boundary of the Reserve. The Milk River has cut a valley through the prairie that is over 400 feet deep and one mile wide. Several deep coulees enter the main river valley. The valley sides, with exposed bedrock and a highly eroded soil, are classified by Wyatt and Newton (1941) as badlands. For a more detailed description of the topography and climate of southeastern Alberta refer to Rand (1948), Soper (1949), and Lewin (1963).

Several distinctive habitats are found on the Reserve. Cottonwood (Populus sargentii), willow and rose grow along the banks of the Milk River where typically Mourning Dove, Yellow Warbler, Bullock's Oriole, and Rufousside Towhee are found. Deer mice and mule deer are regularly observed in the area.

The wide, alluvial valley floor, with the dominant sagebrush (Artemisia cana), winterfat (Eurotia lanata), and greasewood.(Sarcobatus vermiculatus), has little bird life compared to the cottonwood - willow - rose habitat. The

*By Hugh C. Smith, Natural History Contribution Number 8 of the Provincial Museum and Archives of Alberta.
Western Meadowlark is the most common bird of this area, but the Brewer's Sparrow is also encountered here. Among the sagebrush bushes rattlesnakes and garter snakes are found.

The eroded soils and steep sides of the valley deter many plants from occupying this habitat, but greasewood and juniper (Juniperus horizontalis) are two that do occupy it. Rock Wren, Mountain Bluebird and Say's Phoebe are regularly found here.

The prairie level is dominated by grasses with spear grass (Stipa comata), wheat grass (Agropyron spp.), June grass (Koeleria cristata), and blue grama grass (Bouteloua gracilis) the characteristic species present. Horned Larks and Chestnutcollared Longspurs are the most common birds of the grassland, but Ferruginous Hawk, Sharptailed Grouse, Sage Grouse, Long-billed Curlew, and Upland Plover are typically found here. The pronghorn, coyote, rattlesnake, bullsnake, and garter snake also occur in this habitat.

Water resources on the Reserve are alkali sloughs, man-made dugouts and reservoirs, and the Milk River. Willow fringes the borders of many of the dugouts and reservoirs. Mallard, Pintail, Wilson's Phalarope, Red-winged Blackbird and muskrat frequent these fresh water bodies; American Avocet and Willet prefer the alkali sloughs; while Great Blue Heron, Spotted Sandpiper, and beaver are seen along the Milk River.

\section{Previous Surveys of Southern Alberta}

Bird and mammal surveys of southern Alberta have been conducted by Williams (1946); Soper (1946); and Rand (1948). Regionally, Soper (1949) reported on the birds and mammals of the former Nemiskam National Park, a similar area 30 miles northwest of the Pinhorn Provincial Grazing Reserve. 
Field trips to the Pinhorn Reserve were made by Provincial Museum staff in connection with exhibit studies in 1968, 1969, and 1970, and lasted from two to nine days. Four days (May 12 to May 15) were spent on the north section of the Reserve in 1969; in 1970 six days were spent on the south section and three days on the north section (May 26 to June 3). Field notes by M. J. Hampson, J. Keizer, D. A. E. Spalding and the author constitute the basis for this paper. There are 98 species of birds and 13 species of mammals recorded for the Reserve. These do not represent all the species that may occur there, as no trips were made during either the spring or fall migrations, or during the winter. No systematic trapping program was carried out to sample the small mammal population.

The Pinhorn Reserve is divided into north and south sections by the Milk River, and for ease of reference I have called these the north and south Pinhorn Reserve. Several records are listed for nearby localities outside the Reserve.

The species list follows the nomenclature and arrangement of the Checklist of North American birds (A.O.U., 1957).

\section{Acknowledgments}

I would like to thank the following people who kindly read this manuscript, and for the many suggestions they offered: $M$ J. Hampson, J. O. Hrapko, D. A. E. Spalding and J. E. Storer; G. A. Frasier for drawing the map; and the manager and staff of the Pinhorn Grazing Reserve for permitting us to camp on the Reserve and carry out our programs.

\section{SPECIES LIST BIRDS}

Red-necked Grebe. One was seen on a reservoir, south Pinhorn Reserve May 28, 1970. Rand (1948) considered this species uncommon and neither Williams (1946) nor Soper (1949) recorded it.

Eared Grebe. Seen twice in 1970: two, May 28, south Pinhorn Reserve, and three, May 29, near Philip Coulee. Both Rand (1948) and Williams (1946) considered it common, but Soper (1949) did not mention it.

Great Blue Heron. On May 13, 1969 and May 27, 1970, single individuals were seen flying along the Milk River. Rand (1948) reported it as an uncommon summer residen't.

Canada Goose. Common resident. On May 14, 1969, two nests were found near dugouts. One nest that was examined contained seven eggs. Pairs were seen daily along the Milk River. In 1970 flocks of 19,2 , and 4 flew over our campsite.

Mallard. Common resident. Found on every body of water. They doubtless nest around permanent water in the area.

Gadwall. Fairly common in 1970. Small groups were seen on reservoirs, south Pinhorn Reserve, and along the Milk River. Only one observation in 1969: May 14, one on a dugout, north Pinhorn Reserve.

Pintail. Probably the most common duck. Two nests, south Pinhorn Reserve: one containing eight eggs, May 26, 1970; another with five eggs, May 31,1970 .

Green-winged Teal. Recorded only once: May 28, 1970, a number on a reservoir, south Pinhorn Reserve.

Blue-winged Teal. Observed in all bodies of water in 1969 and 1970. Both Williams (1946) and Rand (1948) considered it common.

Cinnamon Teal. A male was seen on a dugout, north Pinhorn Reserve, May 12 and 14, 1969. Neither Williams (1946) nor Rand (1948) list this species. Salt and Wilk (1956) considered it a scarce summer residen't that may breed in southern Alberta.

American Widgeon. Common, seen regularly in 1969 and 1970 on most bodies of water. No doubt breeding, as several pairs were noted.

Shoveler. Common on most bodies of water. Pairs and small flocks were observed daily in 1969 and 1970.

Lesser Scaup. In 1970 flocks were seen on reservoirs, south Pinhorm Re- 
serve; however, only one was seen in 1969.

Turkey Vulture. On June 3, 1970, one was closely observed on a fence post by T. C. Wyn-Evans, botanical assistant. Soper (1949) does not record this species for Nemiskam National Park; Rand (1948) does not include it; Williams (1946) recorded one on the Montana side of the Milk River.

Cooper's Hawk. One was observed on May 13, 1969, in the valley of the Milk River.

Swainson's Hawk. One, June 5, 1968, vicinity of the north Pinhorn Reserve. Williams (1946) considered it common between Coutts and Aden, an area slightly west of the Pinhorn Reserve. Rand (1948) stated that it was not common in 1945; and at Nemiskam National Park, Soper (1949: 177) said it was "far from common in the district."

Ferruginous Hawk. Not common but seen occasionally throughout the area. A nest with three eggs located May 31, 1970, south Pinhorn Reserve. Williams (1946: 51) claimed it the "commonest bird of prey," Soper (1949: 177) said it was the "common hawk of the park." Rand (1948: 16) mentions seeing six birds in an area from the "Dominion Range Station, south to Milk River, and east to the Wild Horse." This area is just east of our study area.

Golden Eagle. Three seen June 5, 1968, near the north Pinhorn Reserve. In 1970, one, near the Aden Post Office, and two near Philp Coulee. Williams (1946) cites observations of single birds at various places, and Rand (1948) mentions Waterton Lakes Park as the only locality where he saw it. Soper (1949) does not record it for Nemiskam National Park.

Marsh Hawk. Not common, although hawks of this species were seen daily in 1969 and 1970. Rand (1948) did not consider it common in the area between Brooks to Milk River. Williams (1946) recorded it as fairly common in 1924. Soper (1949) noted it in Nemiskam National Park.

Prairie Falcon. One was seen over the Milk River valley in 1968 and another in 1970. A pair was observed in the vicinity of the Lost River in 1969. From their behavior it appeared that they had a nest nearby.

Sparrow Hawk. Seen once in 1969 and 1970, along the river flats. One was seen in 1968 flying over the prairie near the rim of the Milk River valley. To Williams (1946) it was a common bird in 1923 and 1924; however, Rand (1948) saw only a few in 1945. Soper (1949) does not mention it for Nemiskam National Park.

Sharp-tailed Grouse. In 1969 and 1970 dancing grounds were found, and a number of birds were encountered at both places. In 1969, a dancing ground was under observation for four days, north Pinhorn Reserve. Counts of 9 and 13 birds were made on two occasions. In 1970, near Philp Coulee, south of the Milk River, another dancing ground with 15 to 20 birds was found.

Sage Grouse. In 1969, one was seen in the study area, and others were seen nearby. None was seen in 1970 .

Ring-necked Pheasant. Several were heard along the Milk River in 1969. On May 26, 1970, six cock pheasants were seen in the vicinity of the Aden Post Office. Whenever we were along the Milk River pheasants could be heard calling.

Gray Partridge. Two were seen May 27, 1970, south Pinhorn Reserve.

Killdeer: Seen on the north Pinhorn Reserve, May 14, 1969. In 1970, south of the Milk River, we considered them common. Recorded May 26 at the Pinhorn Post Office; May 26 at a reservoir, south Pinhorn Reserve; and along the Milk River, May 30. Williams (1946), Rand (1948), and Soper (1949) all considered it common.

Black-bellied Plover. On May 30, 1970, a straggler was seen on a slough, south Pinhorn Reserve.

Long-billed Curlew. Not common, but seen regularly. One was seen north Pinhorn Reserve, June 5, 1968; two, in the same area, May 15, 1969. In 1970, observed: May 26 near the Aden Post Office; May 29, three near Philp Coulee; and June 2, two, north Pinhorn Reserve. 
Upland Plover. On May 29, 1970, near Philp Coulee two were collected and two others seen.

Spotted Sandpiper. One or two were seen daily along the Milk River in 1969 and 1970. One was seen at the Aden border crossing on May 26, 1970.

Willet: Common around dams and sloughs, south Pinhorn Reserve. Several were seen May 28, 1970, flying past our campsite. On the north Pinhorn Reserve, one was seen May 13, 1969, and two on June 2, 1970.

Marbled Godwit: Marbled godwits were seen only on the north Pinhorn Reserve: two on May 14, 1969, and one on June 2, 1970. Rand (1948) found it common in the Brooks area but did not see it elsewhere.

American Avocet. Common around alkali sloughs, south Pinhorn Reserve. Fourteen were seen on May 15, 1970, north Reserve.

Wilson's Phalarope: The most common shorebird, present on every body of water. Two nests, with four eggs each, were found on the south Pinhorn Reserve in 1970.

California Gull. Although gulls were regularly seen in the area, on only one occasion was there a positive identification of this species; one was seen on June 2, 1970, on the north Pinhorn Reserve.

Ring-billed Gull. Four were seen on May 29, 1970, near Philp Coulee, and four along the Milk River near the Reserve headquarters on May 20, 1970.

Black Tern. On May 15, 1969, four were seen, north Pinhorn Reserve; May 28, 1970, several on a reservoir, south Pinhorn Reserve.

Mourning Dove. A common resident of the Milk River valley. Seen daily flying from the river valley to trees in a farm shelter belt nearby. On June 5,1968 , a nest with one egg was found.

Great Horned Owl. Near the Pinhorn Reserve headquarters, one was seen May 30, 1970, and a dead one was found nearby.

Burrowing Owl. Seen on only two occasions in 1970; one, June 1 , north of the Aden bridge, and three June 2, near the Milk River east of Comrey.

Belted Kingfisher. One was seen on May 30, 1970, flying along the Milk River.

Flicker. Flickers, with both red and yellow wing linings, were observed along the Milk River. As none was collected, no determination can be made regarding hybridization.

Red-headed Woodpecker. On June 27,1969 , in the vicinity of the Lost River, one flew across the road in front of our truck.

Downy Woodpecker. Single birds were seen twice along the Milk River, once on May 30, 1970.

Eastern Kingbird. Not uncommon south of the Milk River, although not seen in any numbers. In 1970 single

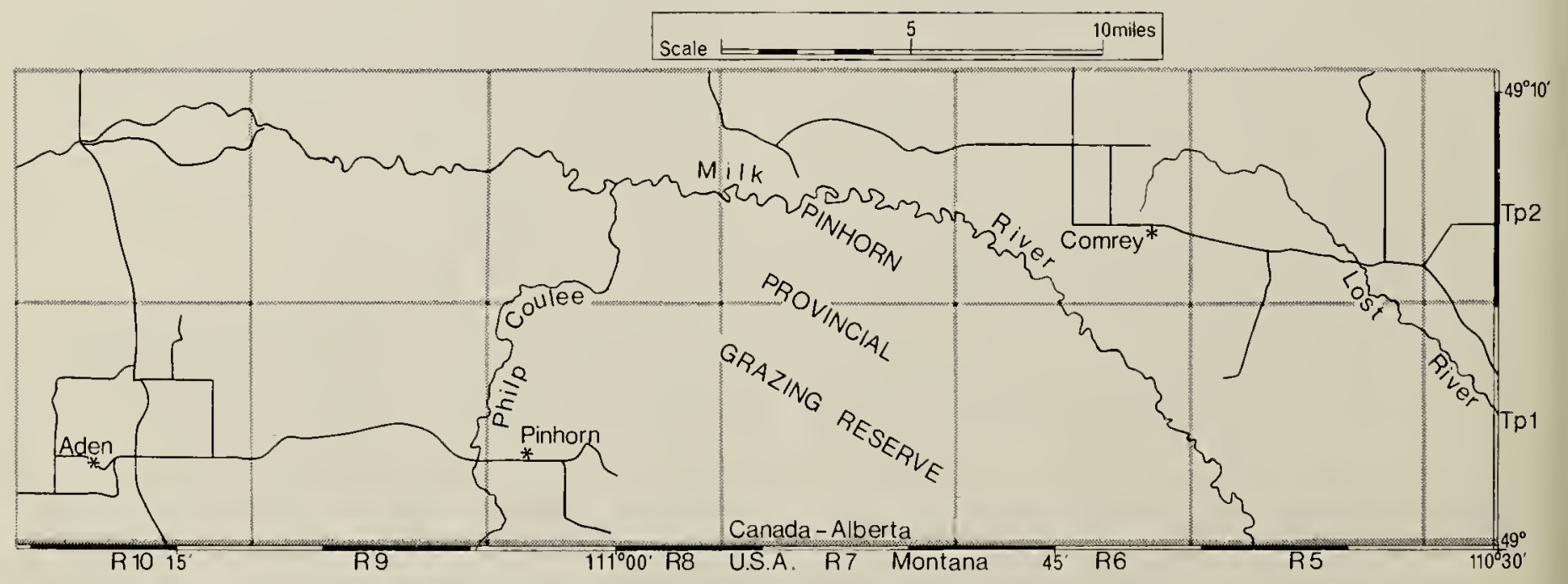

Fig. 1. Map of Pinhorn Provincial Grazing Reserve in southeastern Alberta. 
birds were observed around farm shelter belts and along the coulees of the Milk River. In 1968 two flocks of seven birds were seen.

Western Kingbird. Seen once, on May 26, 1970. One was seen at Aden Post Office.

Say's Phoebe. Seen regularly along the sides of the Milk River valley, but never more than one or two at a time.

Least Flycatcher. Whenever there were willows these flycatchers could be heard calling. Recorded in both 1969 and 1970 from along the Milk River. One bird was collected on May 28, 1970.

Western Wood Pewee. Rand (1948) considered it common along the Milk River. We recorded it only once: May 30, 1970, one seen along the Milk River.

Olive-sided Flycatcher. One, May 10, 1970, seen along the Milk River.

Horned Lark. One of the most common species, encountered throughout the area. Two young were banded in 1970 , one on May 28 and one on May 30, 1970.

Violet-green Swallow. Two were seen on June 1, 1970, flying over the Milk River valley. Not recorded by Williams (1946), Rand (1948), or Soper (1949).

Tree Swallow: Recorded along the Milk River, May 14, 1969.

Bank Swallow. Common locally. Seen at Philp Coulee, May 29, 1970, and again on May 29, 1970, and again on May 30, 1970, near the Pinhorn Re. serve headquarters.

Barn Swallow. Two were seen on May 14, 1969, north Pinhorn Reserve; two, May 27, 1970, south Pinhorn Reserve. Not common on the prairies, as Williams (1946) records it on four occasions, Rand (1948) only once, and Soper (1949) once.

Cliff Swallow. Common and in colonies at the Aden Bridge on May 26, 1970, along Philp Coulee on May 29, 1970 , and at various places along the Milk River.

Black - billed Magpie. Along the wooded banks of the Milk River, Magpies were fairly common in 1969 and 1970.

Common Crow: Recorded on only two occasions: May 14, 1969, north
Pinhorn Reserve; May 27, 1970, several, south Pinhorn Reserve.

Black-capped Chickadee. Found along the Milk River on the Pinhorn Reserve. On May 14, 1969, birds were seen carrying food, although no nesting site could be found. Two were seen May 27, 1970, south Pinhorn Reserve.

House Wren. Fairly common along the Milk River, recorded on May 13 and 14, 1969, and May 30, 1970.

Rock Wren. Along the coulees of the Milk River they were frequently encountered. We recorded them on June 6,1968 , May 14, 1969, and May 27, 1970.

Catbird. Williams (1946) and Rand (1948) stated that it was locally common, but we recorded it only once, May 30, 1970, near the Reserve headquarters along the Milk River.

Brown Thrasher. Reported twice in 1970: May 28, one was collected on the south Pinhorn Reserve near the United States border; May 30, one was seen near the Reserve headquarters.

Robin. Not common along the Milk River, recorded on May 13, 1969, and May 30, 1970.

Swainson's Thrush. On May 30, 1970 , one was seen among willows along the Milk River near the Reserve headquarters. Williams (1946) recorded it, but was doubtful of its identity as it was only heard; Rand (1948) considered it a migrant in southern Alberta; and Soper (1949) does not record it for Nemiskam National Park.

Mountain Bluebird. Relatively common throughout the area. Adult and juvenile birds were seen June 27, 1969, near Lost River. On May 27, 1970, a pair was seen on the prairie, south Pinhorn Reserve; the male was collected.

Sprague's Pipit. Every day we were on the area, and at almost every stop we made on the prairie, they could be heard singing.

Loggerhead Shrike. Not common, seen occasionally throughout the area. June 5,1968 , a nest with 5 eggs; June 27 , 1969, a family group along the Lost River valley.

Common Starling. May 26, 1970, a nest was located near a cabin, south 
Pinhorn Reserve. Some were seen on May 30, 1970, near the Reserve headquarters. Not reported by Williams (1946), Rand (1948), or Soper (1949).

Red-eyed Vireo. One was seen near the Reserve headquarters, May 30, 1970.

Yellow Warbler. Relatively common and singing along the river flats where there were shrubby thickets. Sight records: May 14, 1969, and May 30, 1970, on the river flats, and May 26, 1970, at Aden Post Office.

Myrtle Warbler. One was seen on May 13, 1969, along the Milk River.

Blackpoll Warbler. A male was collected on May 13, 1969.

Yellowthroat. Fairly common along the Milk River. Recorded on the Pinhorn Reserve in 1969 and 1970.

Yellow-breasted Chat. One male was seen on May 30, 1970, near the Reserve headquarters.

House Sparrow. Common around farms and granaries. Recorded on May 26, 1970, at the Aden Post Office. Not seen on the Pinhorn Reserve.

Western Meadowlark. Common throughout the area. Found on the prairie level and on sagebrush flats. along the Milk River. Recorded on May 13, 1969, and May 30, 1970, on the Pinhorn Reserve.

Yellow-headed Blackbird. A large flock was seen once, May 27, 1970, south Pinhorn Reserve.

Red-winged Blackbird. Found wherever there was water with emergent vegetation. In 1970, south Pinhorn Reserve, two nests were found. Four adult birds were banded on May 26, 1970.

Baltimore Oriole. One was seen at Aden Posit Office on May 26, 1970.

Bullock's Oriole. Not common, but found nesting in cottonwoods along the Milk River near the Pinhorn headquarters. Two males were collected, May 27, May 30, 1970.

Brewer's Blackbird. Recorded only once, May 28, 1970, a small flock near a cabin, Pinhorn Reserve. Soper (1949) found them common in Nemiskam National Park, as did Williams. (1946). Rand (1948) recorded small numbers in the vicinity of the Dominion Range Station.

Common Grackle. Two were seen May 13, 1969, north Pinhorn Reserve. Not reported by Soper (1949) or Williams (1946). Rand (1948) recorded them as not uncommon but of local occurrence.

Brown-headed Cowbird. Seen daily around the range cattle; recorded, May 14, 1969, and May 28, 1970.

Pine Grosbeak. M. J. Hampson reported seeing an immature male May 30, 1970, along the Milk River near the Reserve headquarters.

Pine Siskin. A flock was seen along the Milk River on June 1, 1970.

American Goldfinch. Four were seen on May 30, 1970, at Aden Post Office.

Rufous-sided Towhee. In the thick shrubbery along the Milk River, towhees were common. Recorded: May 13, 1969 (one male collected); May 27, 1970 (two males collected); May 30, 1970.

Lark Bunting. Recorded once, two males near Pinhorn Post Office, May 26,1970 . This is in contrast to Williams (1946), Rand (1948), and Soper (1949) who reported it as common in their surveys.

Savannah Sparrow. One was seen May 31, 1970, south Pinhorn Reserve. This was our only record for this species.

Baird's Sparrow. Recorded: June 5, 1968, north Pinhorn Reserve; May 26, 1970, Aden customs port; near Philp Coulee, May 29, 1970, one collected.

Vesper Sparrow. Common throughout the area. Recorded on the north Pinhorn Reserve, June 5, 1968, and May 15, 1969.

Lark Sparrow. Not common, but recorded on the North Pinhorn Reserve, June 5, 1969, and on the south section May 27, 1970, one collected.

Chipping Sparrow. Three along the Milk River, May 14, 1969; four, at Aden Post Office, May 30, 1970.

Brewer's Sparrow. Seen along the Milk River and on the prairie. On May 27, 1970, one was collected.

White-crowned Sparrow. One, May 13, 1969, along the Milk River. 
McCown's Longspur. Small flocks were seen, May 28, 1970, south Pinhorn Reserve. One was collected.

Chestnut-collared Longspur. Along with the Horned Lark, this was probably the most common bird in the area. Recorded in 1968, 1969, and 1970. Two were collected in 1970 . Two nests were found on the south Pinhorn Reserve, on May 31, 1970, one had four eggs, the other had two young birds approximately three days old.

\section{MAMMALS}

\section{Coyote.}

Canis latrans. In 1969, two were heard on May 13. Two were seen in 1970: May 27, south Pinhorn Reserve; June 3, north Pinhorn Reserve.

Richardson's Ground Squirrel. Spermophilus richardsonii. The most notable feature of the fauna of the Pinhorn Reserve was the absence of these rodents. They were common at Manyberries, about 30 miles north, but entirely absent from the Reserve. One was seen June 1, 1970, north of the Aden Bridge.

\section{Pocket Gopher.}

Thomomys talpoides. Tunneling by pocket gophers was evident on many earth dams in the area. One was collected on May 30, 1970, south Pinhorn Reserve. Soper (1946) records two occurrences, one west of Writing-onStone and another in Twp. 2, Rge. 9, just west of our study area.

\section{Olive-backed Pocket Mouse}

Perognathus fasciatus. While driving the prairie trails at night we caught two pocket mice by hand, May 27, 1970, south Pinhorn Reserve. Soper (1946) does not mention this mouse as occurring in Alberta.

\section{Beaver.}

Castor canadensis. Beaver trails and cuttings were seen at many places along the Milk River in 1969 and 1970.

\section{Deer Mouse.}

Peromyscus maniculatus. In three nights in 1969, 20 were caught in traps. In 1970, during the night of May 26, several were caught by hand and released.

\section{Meadow Vole.}

Microtus pennsylvanicus. On May 13, 1969 , one was caught by hand. This was the only meadow vole we saw during our field work on the Reserve.

\section{Muskrat.}

Ondatra zibethicus. On the south Pinhorn Reserve, muskrats were seen in several reservoirs. On May 27, 1970, two were trapped.

Nuttall's Cottontail

Sylvilagus nuttallii. Fairly common along the Milk River. One was seen June 5,1968 , and several were seen and three collected May 27 and May 30, 1970.

\section{White-tailed Jack Rabbit.}

Lepus townsendii. One was seen May 26, 1970, at Aden Post Office, and two were seen on the south Pinhorn Reserve on May 27, 1970.

\section{Mule Deer.}

Odocoileus hemionus. Observed on several occasions both north and south of the Milk River: June 5, 1968, seven on the north Pinhorn Reserve; May 14, 1969, six seen near the Milk River on the north Reserve; May 29, 1970, two seen at Philp Coulee; and May 30, 1970, one seen on the south Pinhorn Reserve.

White-tailed Deer.

Odocoileus virginianus. One was seen June 1, 1970, on the north Pinhorn Reserve.

\section{Pronghorn.}

Antilocapra americana. Pronghorn were seen daily in 1969 and 1970.

\section{LITERATURE CITED}

American Ornithologists' Union. 1957. Checklist of North American birds. Fifth Ed., Baltimore, Maryland, U.S.A. pp. 691.

Lewin, V. 1963. The herpetofauna of southcastern Alberta. Can. Field-Nat.. 77:203-214.

Rand, A. L. 1948. Birds of southern Alberta. Nat. Mus. Can., Bull 111, Biol. Series 37.

Salt, W R., and A L Wilk. 1966. The birds of Alberta. Dept. Industry and Development, Edmonton.

Soper, J. D. 1946. Mammals of the Northern Great Plains along the International Boundary of Canada. Journ. Mamm., 27: 127-153.

Soper, J. D. 1949. Notes on the fauna of the former Nemiskam National Park and vicinity, Alberta. Can. Field-Nat., $63: 167$ 182.

William, M. Y. 1946. Notes on the vertebrates of the Southern Plains of Canada, 19231926. Can. Field-Nat., $60: 47-60$.

Wyatt, F. A., J. D. Newton, W. E. Bowser and W. Odynsky. 1941. Soil survey of Milk River Sheet. Dom. Dept. Agri., Exp. Farm Service, pp. 1-105. 